\title{
DEVELOPMENT TRAJECTORIES OF SMALL TOWNS IN EAST SLOVAKIA
}

\author{
Ladislav Novotný, Stela Csachová, Marián Kulla,
} Janetta Nestorová-Dická, Loránt Pregi ${ }^{1}$

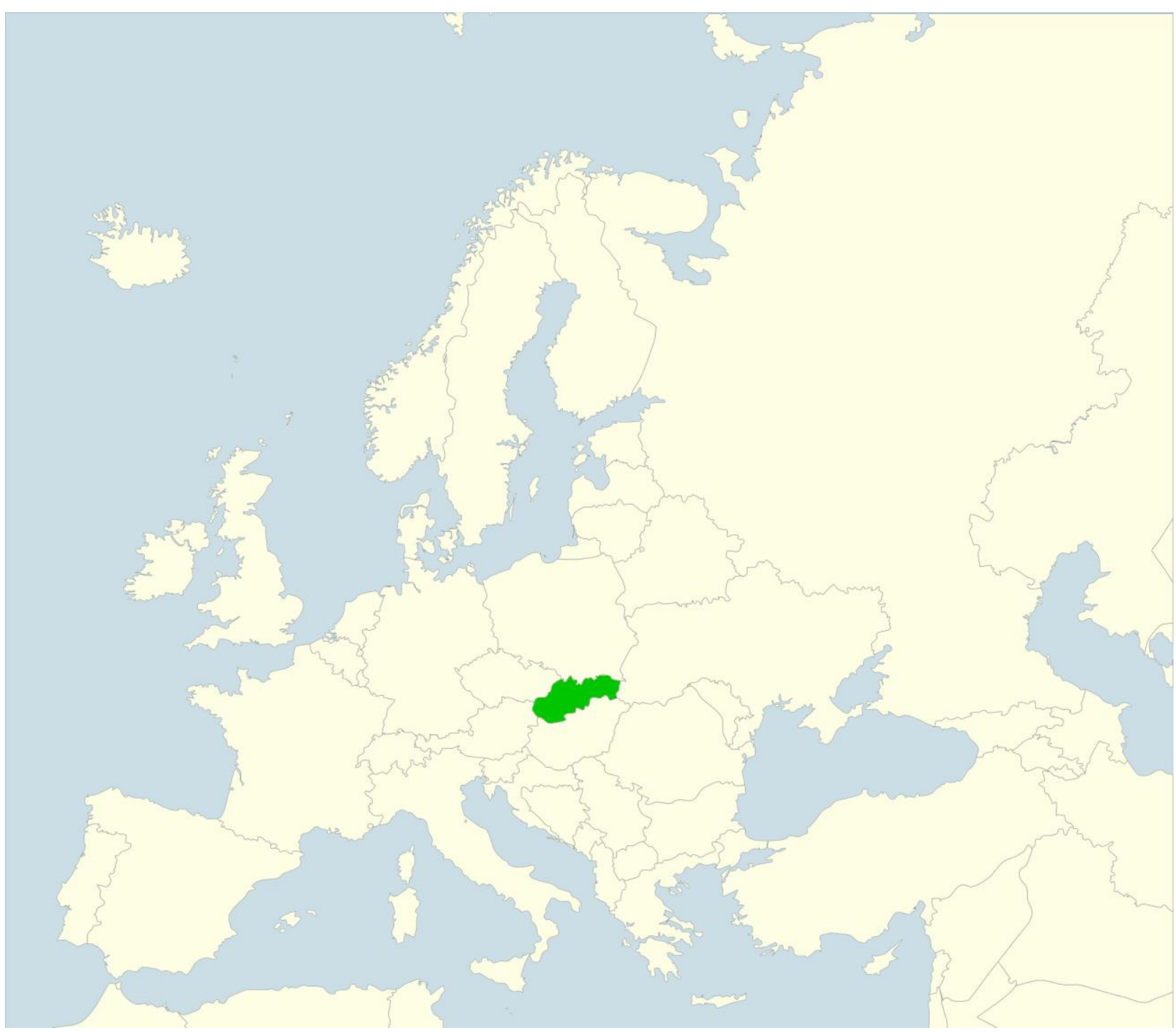

\footnotetext{
${ }^{1}$ Mgr. Ladislav Novotný, Ph.D., RNDr. Stela Csachová, Ph.D., Mgr. Marián Kulla, Ph.D., RNDr. Janetta NestorováDická, Ph.D., Mgr. Loránt Pregi, Institute of Geography, Faculty of Science, Pavol Jozef Šafárik University in Košice, Jasenná 5, 04001 Košice, Slovakia, e-mails: ladislav.novotny@upjs.sk; stela.csachova@upjs.sk; marian.kulla@upjs.sk; janetta.nestorova-dicka@upjs.sk; lorant.pregi@upjs.sk
} 


\begin{abstract}
Small towns, compared to larger cities, are specific group of municipalities with weaker performance in many spheres of socio-economic development. The aim of the paper is to comprehensively evaluate development of twelve small towns in the region of East Slovakia over the centuries up to present. The paper deals with question how their demographic and economic developments have been reciprocally influenced under particular historical circumstances. Using various sources of statistical data and employing traditional historical, mathematical-statistical and cartographical methods, regularities and patterns were identified that enabled us to categorize small towns and evaluate their development trajectories and current roles in the settlement system. In the most cases, they are still valid nodes for their hinterlands even though their past situation has been unfavourable.
\end{abstract}

Keywords: small towns, East Slovakia, population, economy, commuting

\begin{abstract}
Abstrakt: Malé mestá sú špecifickou skupinou sídel s prienikom urbánnych i rurálnych čŕt, ktoré sa $v$ porovnaní $s$ väčšími mestami vyznačujú menším výkonom $v$ rôznych oblastiach socio-ekonomického rozvoja. Ciel'om príspevku je na príklade východného Slovenska identifikovat' a zhodnotit' trajektórie vývoja malých miest. Snahou je zhodnotit' vzájomný vplyv demografického a hospodárskeho vývoja $\checkmark$ historickej perspektíve $s$ dôrazom na post-socialistickú transformáciu. $V$ príspevku sú použité analýzy štatistických dát s kartografickou interpretáciou, ktoré nám umožňujú identifikovat' špecifiká a podobnosti vývoja a následne malé mestá kategorizovat' a zhodnotit' ich úlohu a pozíciu v sídelnom systéme. Výsledky preukazujú, že hoci sa post-socialistická transformácia vo vývoji väčšiny malých miest prejavila nepriaznivo, malé mestá si zachovávajú pozíciu dôležitých centier s obslužnou funkciou pre svoje zázemia.
\end{abstract}

\title{
1. Introduction
}

Urban and rural areas have been developing for years in noticeably distinct way and usually are easily distinguished. The key function of rural areas was the agricultural production. Rural areas were also conceived as a source of population that later migrated to towns and caused their growth and increase of urbanisation. Towns had been developing as centres of market, crafts, industry, and services subsequently. The towns had become a home to many people thanks to plenty of functions. Over the centuries, the territorial distribution of towns had created a network that is specific for each country itself.

The towns are hierarchized at different scales. None doubts the role of the capital and large cities providing most functions to the citizens, however, little attention has been paid to smaller towns located in the peripheral regions of the country. As emphasised by Steinführer and Haase (2007), there are many issues concerning the urban development in Eastern Europe that have not been precisely researched yet, among which is the situation of small towns being in the subordinate position to the larger ones.

The aim of this paper is to provide comprehensive insight into historical and current development of small towns under specific circumstances in East Slovakia. Therefore analyses of various aspects of demographic and economic development are conducted to reveal regularities and patterns of development, and to identify current position of small towns in settlement system. Using the example of East Slovakia, the study is intended to contribute to the research of potential, role and functions of small towns in settlement hierarchy. The territory was chosen due to specific historical and geographical conditions that shaped development of settlement system, which differs from the rest of the country.

The paper's first part discusses the variability of understanding the notion of small cities and towns across the Europe and overseas. The studied region is firstly analysed through the brief 
history of settlement system formation up to the present. Then, before generalisations are drawn, demographic and economic analyses explain the specific development trajectories of small towns which led to their present position in settlement system.

\section{Theoretical and historical background}

\section{Small towns in current geographical research}

In recent scholarly research of urban geography, the issue of small towns aroused the interest of interdisciplinary teams, mainly consisting of geographers and economists. The concept of small towns is deeply researched in Knox and Mayer (2013) and Kresl and letri (2016). The main research question raised was whether small towns had the place or a role to play in a contemporary global economy. The monographs understand small towns with the population threshold to 50 thousands of residents (Knox and Mayer 2013) with distinct subordinate position in the era of global or mega-cities. In their opinion, when small towns focus on their specific characteristics and exploit their opportunities, they can become niches with various scales, mainly regional economies. Their strengths are their own identity, sociable and enjoyable way of life for their inhabitants, traditions (Knox and Mayer 2013), and liveability of public spaces and urban amenities (Kresl and letri 2016).

The most detailed research of small and medium-sized towns in Europe was launched within an ESPON (European Spatial Planning Observation Network) project SMESTO (Small and medium sized towns). A partnership of several European institutions was established to give the different country-profiled conceptions of small towns. The final report on SMESTO (2006) introduces the conceptualisation of small and medium-sized towns, their identification and role in the context of territorial development (Schneidewind et al. 2006). The situation in Portugal is given in Alves et al. (2016). On the basis of concepts of urban shrinkage and urban life-cycle theory, many cities in urban Europe are presently facing, they design particular types of trajectories of small towns. Urban shrinkage was also identified in Australia by MartinezFernandez et al. (2016), even though only towns above 10 thousands were considered. They emphasised the role of regional context to towns' population development. In their opinion, the occurrence of population decline is much more presumed in cities and towns in economically lagging regions.

In the Czechoslovak community of geographers during socialism the topic of small towns has been linked to the geographic workplace in Brno (Czechia) under the auspices of doc. Vaishar. Their works give evidence of the role of small towns in the settlement systems, mainly in the countries and regions of higher territorial fragmentation. Vaishar et al. (2012) considers a small town as a part of rural areas providing the city proper equipment, however not reaching the level of regional centre but mainly providing job offers and services. In the peripheral areas of rural character, where there are no large or middle-sized towns, a kind of "cityness" is secured right by small towns. The same is confirmed by Sýkora and Mulíček (2009) who advocate for small town research, mainly in the understanding the urban-rural interactions in rural regions. Czechia, known for the high territorial fragmentation, is a good example of the autonomy of small towns having less than 5000 inhabitants in terms of their daily life.

The relevance of small towns is recognised through case studies, characterising the small towns and providing their typology. As referred in Kresl and letri (2016), their situation might be resource-based, declining industrial, high technology, recreation and tourism, isolated, peripheral or multi-focused. The survival scenarios for their economies according to ESPON (Schneidewind et al. 2006) suggest restructuring industry, residential economy or knowledgebased economy.

Based upon inspirations from the abovementioned studies, the following paper wants to explore the interdependencies of demographic and economic transformations of small towns in East Slovakia in the recent and past. The major aim is to assess the role these towns perform in regional context. 


\section{Key historical stages of town-forming process in East Slovakia}

Although the town-forming process on the territory of Slovakia had launched earlier (cf. Pašiak 1980 , p. 53), decisive stimulus for establishing new towns came after the Mongolian invasion during 1241 - 1242. Hungarian King Bela IV and his successors promoted urban development in a form of town privileges to selected settlements. The privileges were usually related to tax freedom for German (and Italian in case of Spišské Vlachy) settlers who had been invited to resettle the destroyed areas, contribute to development of crafts and market, and exploit the rich deposits of ores. Settlements with urban character emerged first in West Slovakia. Out of six towns established until the $13^{\text {th }}$ century (Marsina 1973), only Levoča is situated in East Slovakia. Twenty-four settlements in Slovakia were granted the town privileges by Bela IV, nine of them located in East Slovakia. Efforts for further economic development led to a need for establishment and development new towns, predominantly as crafts and market centres. Granting various forms of town privileges continued also in next generations of Hungarian monarchs. By the end of the $16^{\text {th }}$ century, beside small number of free royal towns, there were another fifty towns in East Slovakia, more than today's forty towns and cities. Further development indicates that town network became saturated by the end of the $16^{\text {th }}$ century. No significant stimuli for establishment the new towns came in following centuries. Some of the towns rather lost their roles, status and acquired more rural character or even disappeared.

During the $19^{\text {th }}$ century, stimuli for development of towns became similar between western and eastern parts of Slovakia. The key factors were railways construction and industrialization. Nevertheless, specific attributes of settlement system in East Slovakia persisted from previous era. Although majority of settlements in the East Slovakia was established long before the $19^{\text {th }}$ century, emergence of a few of them is associated with the industrialization of the $20^{\text {th }}$ century. Generally stated, it is possible to distinguish two main categories of towns in East Slovakia, taking into account the period when they gained character of town. Firstly, the historical towns developed before the $16^{\text {th }}$ century are labelled as pre-industrial since their development has been driven mainly by market, crafts, or mining. Secondly, towns established during the $20^{\text {th }}$ century and historical rural settlements that gained character of town in the $20^{\text {th }}$ century are labelled as industrial since their development was directly or indirectly conditioned by process of industrialization.

\section{Classifications of municipalities since the Second World War and selection of analysed towns}

While under Hungarian Kingdom communities obtained status of town by royal decrees and deeds, after establishment of Czechoslovakia a system of classification where decisive role was played by a population size and other town-forming attributes became preferred. In the 1961 population census, very precise categorization of municipalities was employed in Czechoslovakia. Categories of town, small town, agglomerated village, and rural village were adopted. Beside other criteria regarding population density, structure of economy, infrastructure and civil facilities, the number of inhabitants in the municipality was set between 2000 and 5000 for the category of small towns.

As stated by Verešík (1974), there were twelve towns in East Slovakia which meet the 1961's requirements, including Starý Smokovec (currently Vysoké Tatry), Spišské Podhradie, Spišské Vlachy. Other recent towns with population below 5000 were then classified as agglomerated villages (Medzev, Strážske, Podolínec, Giraltovce, Hanušovce nad Topl'ou, and Čierna nad Tisou). By population census in 1970, the number of small towns in East Slovakia increased to twenty-three. Giraltovce, Strážske, Spišská Stará Ves, Podolínec and Hanušovce nad Toplou were re-classified from agglomerated village to small town category.

In the 1980 census, the category of small towns was not recognized and municipalities were reclassified into the categories of towns, agglomerated villages and rural villages. According to this classification there were 37 towns in East Slovakia, eleven of them had less than 5,000 inhabitants. 


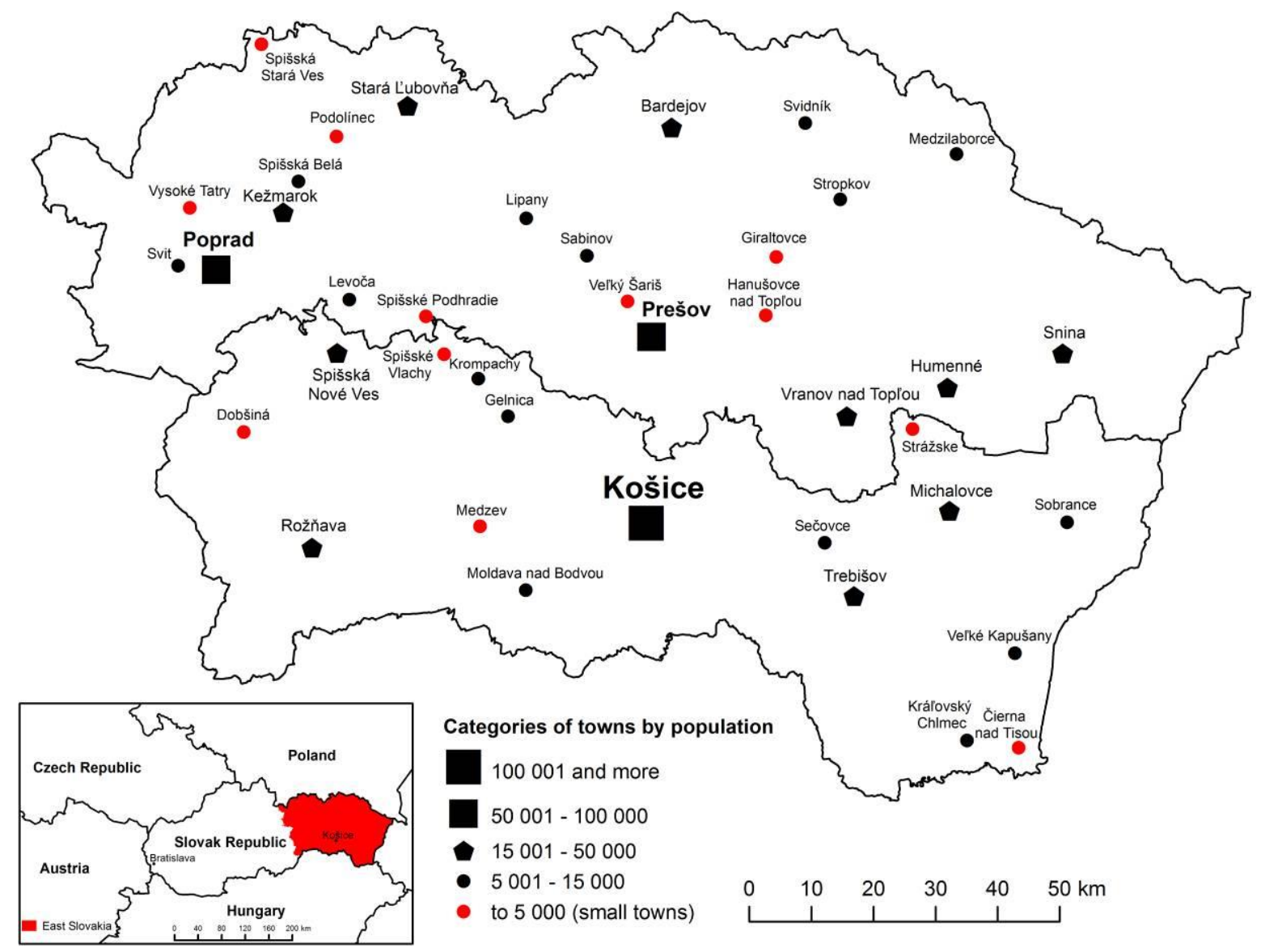

Fig 1. Small towns in East Slovakia (1991 - 2011).

There have been only rural municipalities and towns distinguished in censuses since 1991. To become a town, a municipality has to be granted a status of town approved by the decision of the National Council. The population size is an important attribute, but not a decisive one. Considering this categorization, there were 39 towns in East Slovakia in 1991, 9 of them had population lower than 5,000. By 2001, the number of towns increased to 40 with eleven towns with population below 5,000 . The total number of towns in the region remained 40 till 2011 but the number or these with less than 5,000 inhabitants decreased to 10 .

The methodological procedure of selection the studied town is set on population criterion. All East Slovak municipalities have been granted a status of town with population between 2,000 and 5,000 and at least in one of population censuses in 1991, 2001, and 2011 have fallen into our research. Out of 22 such defined small towns in Slovakia as many as 12 are located in its eastern part. We have observed the following towns (in the alphabetical order): Čierna nad Tisou, Dobšiná, Giraltovce, Hanušovce nad Topl'ou, Medzev, Podolínec, Spišská Stará Ves, Spišské Podhradie, Spišské Vlachy, Strážske, Vel'ký Šariš, and Vysoké Tatry (fig. 1).

In East Slovakia, some towns which only slightly exceeding 5,000 inhabitants were appointed as district seats, what brought them important administrative role and lifted them up in the urban hierarchy. Therefore, considering settlement system and urban hierarchy in East Slovakia, we find towns between 2,000 and 5,000 inhabitants, at the interface of urban and rural, relevant to be considered as small towns.

\section{Methodology and data}

A settlement is referred to a built-up area in which people live making up a community. We mostly use the term of rural or urban settlement to emphasize the historical context implying the preceding forms prior to towns. A term municipality, either of rural or urban character, is used since the settlement gained the administrative function. Rural municipality can be 
associated with a term of village, though this term is not much preferred in geography of settlements in Slovakia. Town is an urban municipality historically associated with privileges or later with a status being granted by a ruler. Town is obviously smaller in size and functions than a city - a term referring to a town exceeding 100,000 which is only rarely used in this paper.

To outline historical development, the information on categorization of towns together with population data are obtained from historical lexicons (FSO 1978, SOSR 2003a) and encyclopaedias by Kropilák (1977a, 1977b, 1978). The data are used to express the population size of studied towns and to show the intensity of population growth over time. It is expressed by population growth rate meaning the number of inhabitants at the end of chosen period expressed as percentage of number of inhabitants at the beginning of given period. Changes in the ethnic structure of population in 1880 and 1910 from historical-demographic lexicon (Majo 2012) complemented the data from the latest population census (SOSR 2011a) and the estimation of Roma population by Mušinka et al. (2014).

Despite certain differences resulting from minor changes in methodologies, political and social situation, as well as general willingness of population to participate in population censuses, population censuses from 1991, 2001 and 2011 (SOSR 1991, 2001 and 2011a) provide comparable data on population appropriate for more detailed analyses. These data are combined with data from Annual registration of population at the level of individual municipalities (ARP) by sex and age (SOSR 2001 - 2014a). To express the development of demographic or economic variables we employed growth index number which reflects percentage change of given value in comparison with a value in reference period. Index number 100 represents unchanged value during given period. Number over 100 implies an increase, below 100 implies a decrease. To express the age-structure of population and its changes over time, total dependency ratio, proportion of persons $0-14$ and 65 years and over and average age are used. In order to simplify visual interpretation, the data from 2001 and 2014, and their comparison, are presented. ARP data (SOSR 2001-2014b) are used to reveal the role of migration and natural reproduction patterns of population in recent total population development.

Evaluating the data from 1991 and 2011 censuses (SOSR 1991 and 2011a) on population structure by age, economic activity of population, sector of economic activity, and on commuting to work (outgoing and ingoing) by economic sector, allow us to examine the economic transformation of towns. Number of jobs occupied by individuals with permanent address in given town (hereinafter referred to as number of jobs for locals) is estimated by deducting number of out-going commuters from total number of economically active people residing in given town. Number of economically active individuals employed in a town of residence expressed as percentage of total number of economically active individuals (including those commuting to other communities) is called local demand satisfaction rate meaning to indicate the ability of a town to provide jobs for its own economically active population (to satisfy its demand for jobs). Total number of jobs in each town is estimated as a sum of number of jobs for locals and number of commuters to work to given town. These data do not provide detailed information on character of jobs, (full-time or part time, temporal or permanent job), but the estimated data for 1991 and 2011 are definitely sufficient to mutually compare the towns and to indicate their development trends during post-socialist period.

Analogically, evaluating the data on sectors of economic activity of population and commuters, numbers of jobs by economic sectors in 1991 and 2011 are estimated for each town, what allows us to assess the importance of individual sectors in the local economy. However, these estimations might be affected by certain distortions, which stem from small differences in categorization of economic activities in 1991 and 2011, and also between categorization for employees in given municipalities and commuters. Thus, category "education and health care" includes also employees in culture in 1991 and employees in public administration in 2011. Category "market and other services" also includes commuters with unidentified economic sector. However, considering numbers of commuters in this category, it could have only minor impact on total numbers and should not significantly affect overall trends.

Jobs that were identified to be localized in the towns for own economically active population include sole traders (proprietorships) who are registered in the town, but might perform the work elsewhere. And analogically, there might be actually some sole traders working in analysed towns 
but they are not counted because the statistics does not catch their real place of work. This fact may also affect overall results, but due to the character of available statistical data, it is not possible to get more properly adjusted data.

Data on commuting at the level of individual municipalities from the three latest population censuses (SOSR 1994a, 2001 and 2011a) were used to outline changes in spatial extent of commuting zones of the small towns and their changing role in regional economies. Data are considered reliable but the level of detail is limited. The commuting flow from community to community (in one direction) is reported only when total number of commuters to work together with pupils and students commuting to schools is at least 10 persons. Smaller flows are not reported separately, but are reported only as "other commuters within the district/from other districts/from abroad". That is why they are not depicted in the maps. Despite these limitations, this is the most detailed data source available for all municipalities and sufficient to outline general development trajectories.

\section{Research results and discussion}

\section{Demographic transformation of small towns}

The earliest reliable data on population of studied municipalities come from the 1869 population census. To present the historical overview of their population development, also the data from the 1921 (after the end of the First World War and creation of Czechoslovakia), the 1950 (beginning of socialist era), the 1991 (after socialist period), and the 2011 (the latest census) population censuses are considered.

Population growth rate enables us to assess the development trajectories during four considerably different historical periods:

1. Austrian-Hungarian rule, before First World War,

2. Democratic Czechoslovakia, Interwar period,

3. Socialist Czechoslovakia, socialist industrialization, urbanization,

4. Independent Slovakia, post-socialist transformation.

The number of inhabitants in each census is calculated for each town in the then administrative borders. Thus, the increase or decrease of population might be influenced also by administrative changes (mergers or splits of municipalities). The development in Vysoké Tatry and Čierna nad Tisou is not captured in the first two periods as the towns were established as late as in the second half of the $20^{\text {th }}$ century.

Population of Slovakia more than doubled during the $1869-2011$ period (tab. 1). Faster growth was recorded in four towns, with extreme (more than fivefold growth) increase in Giraltovce. Čierna nad Tisou and Vysoké Tatry literally surged from zero. On the other hand, four towns recorded population growth smaller than Slovakia as a whole, including Medzev, population of which even decreased. Some regularity in population size development can be identified also when considering the four mentioned periods separately. Spišská Stará Ves and Giraltovce are the only towns with increasing population during all periods and Giraltovce is the only one with the population growth larger than the average for whole Slovakia.

Giraltovce was a small feudal town with a rich history but relatively small population. The growth of population during the period 1869 - 1921 was related to the foundation of enterprises (e.g., production of ceramics, paper mill). After 1921, Giraltovce continued to exploit its favourable location on major route connecting the Baltic Sea with Balkan for further development. Administrative role of the town strengthened as it became the seat of district. Despite continuous growth, the population of Giraltovce was still only about 1,500 by the end of the Second World War. 
Tab 1. Population growth of small towns in East Slovakia from 1869 to 2011.

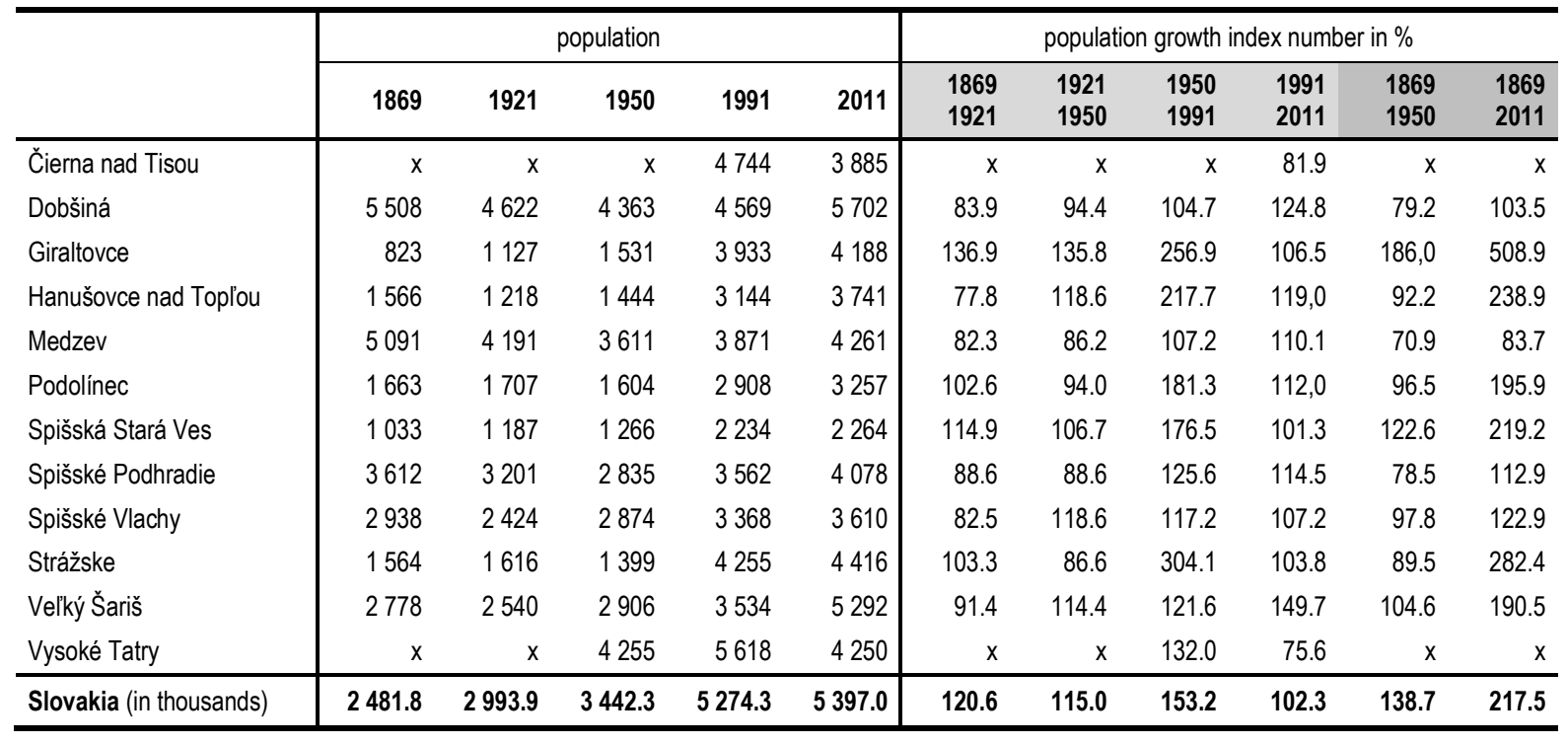

Based on data from FSO 1978, 1984, ÚKLKas MV 1966, SOSR 2003a, $2011 b$

Pre-industrial towns with royal privileges including market rights, such as Spišské Podhradie, Spišské Vlachy, Vel'ký Šariš, Spišská Stará Ves, and Podolínec seem to record their development peak before 1869. All these towns recorded stagnation and even population decline in period 1869 - 1921. It continued over the interwar period, although Spišské Vlachy and Hanušovce nad Topl'ou recorded slight population increase, what might be attributed to favourable location on important railway routes built in this period. Very similar trends were recorded in Medzev and Dobšiná, two medieval mining towns where mining activities ceased when ore deposits had been running out, and after the breakup of Hungarian kingdom and creation of Czechoslovakia in 1918 the towns lost their connection to traditional markets in Hungary and Balkan countries. Population of both mining towns exceeded 5000 in the 1869 population census, but decreased almost by $20 \%$ till 1921 .

Pre-industrial towns started to stagnate and decline also due to the gradual loss of German population who accounted for a significant proportion in these towns (tab. 2). This loss culminated during and after the Second World War, when almost all Germans were expulsed from the territory of Czechoslovakia and subsequently partially replaced by other inhabitants, including the Roma population.

The beginning of socialist era after the Second World War implied considerable abandonment of previous trends. Socialist industrialization and urbanization became stimuli determining further development of analysed towns. The efforts of communist regime to increase the share of urban population in Czechoslovakia and mainly in more rural Slovakia led to selection of towns and central municipalities that were entitled by top-down decisions to concentrate the construction of dwellings and development investments. In the municipalities outside the network of central municipalities, there were investment restrictions, what de facto implied a building ban (cf. Ouředníček 2003). This stimulated population growth in selected small towns, but on average (population growth index number $148 \%$ without Vysoké Tatry and Čierna nad Tisou that were established only in this period) it was slightly smaller than population growth of Slovakia as a whole (153\%).

Clearly divergent development trends can be observed between a group of pre-industrial town's population size of which exceeded 2000 in 1950 (Medzev, Dobšiná, Spišské Podhradie, Spišské Vlachy, Vel'ký Šariš), and a group of towns with smaller population at the beginning of socialist era. The latter group includes smaller pre-industrial towns and industrial towns with predominantly rural history (Podolínec, Spišská Stará Ves, Hanušovce nad Topl'ou, Giraltovce, Strážske). Population growth in the larger pre-industrial towns was insignificant. The average population growth index number in the period 1950 - 1991 was only 114\%. Although the most intensive construction and urban growth in modern history of Slovakia was recorded during this period (cf. Slavík and Grác 
2009) it did not apply to these towns which recorded rather population stagnation. The average growth index number in the group of smaller towns reached over $227 \%$, so the population of these towns more than doubled on average. The fastest growth index number (304\%) was recorded in Strážske which is a result of establishment of chemical manufacturing plant (Chemko) in 1952 producing the explosives for military and civilian purposes (Chemko 2015). The factory itself was employing 4,000 workers at its peak (Mládek 1990). Together with other companies, the town of Strážske became an important regional centre of employment.

Development of economic activities (timber production, climatic spa, tourism) in the Vysoké Tatry mountain area (High Tatras) induced the establishment of the Vysoké Tatry town on the territory of older settlements in the mountainous area. The newly established town underwent many administrative changes with some adjacent settlements having merged to the town and other gaining administrative autonomy. Nevertheless, the town was continuously losing its population since its establishment until 1990, when Tatranská Lomnica (the largest settlement) joined Vysoké Tatry again. Generally, the town`s population grew during the $1950-1991$ period, but similarly with the group of larger pre-industrial towns, the population growth was smaller than in Slovakia as a whole.

Since Czechoslovakia became part of the Eastern Bloc, the need to build a railway transhipment station for goods exchange with the Soviet Union arose also due to different railway gauges in both countries. The construction of both, the station and the town of Čierna nad Tisou started in 1946. In the 1960 population census, a town had 1704 inhabitants and that number almost tripled by 1991 (4744 inhabitants). Thus, the development trajectory of this town seems to be very similar with aforementioned group of smaller towns during socialist era.

During 1991 - 2011 period, population of Slovakia as a whole reported only insignificant growth (tab. 1). This is related to destructive phase of natural reproduction behaviour of population from previous era resulting into stabilization natural increase close to equilibrium (Mládek 2008). Similarly, migration patterns from socialist era collapsed in the early 1990s and the number of migrations in Slovakia decreased significantly. Generally, new migration patterns became clearly recognizable only after 2000 (cf. Bezák 2006, Šprocha 2011). Stabilized development is observed also in the studied small towns. Fair population decline was recorded in the two youngest towns of Vysoké Tatry and Čierna nad Tisou. Other small towns recorded slight population growth with Vel'ký Šariš reaching the highest growth index number (150\%).

Ethnic structure of population often displays cultural, architectural and economic development of municipalities and regions and may considerably affect migration and natural reproduction of population (cf. Gabal 1999). Hungarian and German ethnic groups record lower values of natural increase than Slovak, although the differences are insignificant in comparison to extremely high values recorded by Roma population (cf. Podolák 2000, Pukačová and Mládek 2014, Sprocha 2014). Assessing the changes in the ethnic structure, we seek to clarify the context either of the population growth or decline in the analysed towns.

During the researched period, the impact of ethnic structure on migration was most significant after the Second World War when German population was almost completely expulsed from Czechoslovakia, what affected many small towns. By the end of the $19^{\text {th }}$ century, German population accounted for 20 to $90 \%$ of population in larger pre-industrial (especially mining) towns (tab. 2). Before the First World War, proportion of population declaring Hungarian ethnicity reached significant values, which is attributed to assimilation of German and Slovak population with Hungarian majority (Uličný 1992, Marenčáková 2006, p. 103). After the Second World War, proportion of Hungarian and German population dropped almost to zero. The only exception is Medzev, where German population still constitutes over $8 \%$ of population and Čierna nad Tisou with almost two thirds of population declaring Hungarian ethnicity.

Roma ethnicity was officially not recognized during the socialist population censuses ${ }^{2}$ and Roma people had to declare some other ethnicity. The consequences of these restrictions still persist, even though it is on a voluntary basis now. In population censuses, majority of Roma

\footnotetext{
${ }^{2}$ Although in socialism the Roma ethnicity was recorded, it was not possible to declare officially it in the censuses.
} 
people tend to declare Slovak or Hungarian nationality, depending on ethnicity constituting the majority in given municipality. To estimate more credible proportion of Roma population, data from the Atlas of Roma communities (Mušinka et al. 2014) are used in this analysis.

Tab 2. Proportion of major ethnic groups* on total population of East Slovak small towns.

\begin{tabular}{|c|c|c|c|c|c|c|c|c|c|c|}
\hline & \multicolumn{3}{|c|}{ Slovak } & \multicolumn{3}{|c|}{ Hungarian } & \multicolumn{3}{|c|}{ German } & \multirow{2}{*}{$\frac{\text { Roma* }^{*}}{2013}$} \\
\hline & 1880 & 1910 & 2011 & 1880 & 1910 & 2011 & 1880 & 1910 & 2011 & \\
\hline Čierna nad Tisou & $\mathrm{x}$ & $\mathrm{x}$ & 33.4 & $x$ & $x$ & 62.3 & $\mathrm{x}$ & $x$ & 0.0 & 12.9 \\
\hline Dobšiná & 22.8 & 29.9 & 71.6 & 6.4 & 34.6 & 0.2 & 66.2 & 33.6 & 0.1 & 36.8 \\
\hline Giraltovce & 74.7 & 50.6 & 77.9 & 6.8 & 38.6 & 0.0 & 11.2 & 6.0 & 0.0 & 22.3 \\
\hline $\begin{array}{l}\text { Hanušovce nad } \\
\text { Topl'ou }\end{array}$ & 71.7 & 59.3 & 79.1 & 1.1 & 23.8 & 0.1 & 22.3 & 9.2 & 0.0 & 24.9 \\
\hline Medzev & 1.8 & 3.1 & 69.8 & 7.4 & 22.4 & 1.3 & 86.3 & 72.2 & 8.3 & 30.3 \\
\hline Podolínec & 31.5 & 43.7 & 88.0 & 3.9 & 10.8 & 0.1 & 60.1 & 45.3 & 0.1 & 14.9 \\
\hline Spišská Stará Ves & 73.1 & 54.8 & 90.8 & 1.0 & 12.4 & 0.0 & 18.4 & 21.7 & 0.0 & 8.3 \\
\hline Spišské Podhradie & 66.7 & 58.9 & 83.6 & 2.2 & 19.2 & 0.1 & 26.3 & 21.3 & 0.0 & 14.0 \\
\hline Spišské Vlachy & 56.7 & 66.8 & 93.8 & 8.2 & 14.1 & 0.1 & 32.2 & 18.2 & 0.0 & 10.4 \\
\hline Strážske & 90.3 & 78.2 & 90.3 & 4.0 & 11.6 & 0.3 & 2.3 & 7.0 & 0.0 & 11.4 \\
\hline Vel'ký Šariš & 86.2 & 75.5 & 82.2 & 1.1 & 16.9 & 0.1 & 7.0 & 3.0 & 0.0 & 11.9 \\
\hline Vysoké Tatry & $x$ & $x$ & 83.3 & $x$ & $x$ & 0.4 & $x$ & $x$ & 0.1 & 0.0 \\
\hline Slovakia & 61.0 & 57.8 & 80.7 & 22.2 & 30.3 & 8.5 & 9.3 & 6.8 & 0.1 & 7.5 \\
\hline
\end{tabular}

Based on data from Majo (2012), SOSR (2011a) and **Mušinka et al. (2014); *ethnicity in 1880 and 1910 was derived from first language of inhabitants

\section{Recent demographic trends in small towns}

Population ageing became one of the most critical demographic processes in Slovakia after the fall of communist regime (Mládek and Kačerová 2008, Kačerová 2009). Population of East Slovakia is relatively young due to high proportion of Roma population as well as stronger positive impact of religion to reproductive behaviours of population. Despite considerable differences, it is possible to conclude that development trends in majority of analysed towns converge with those recorded for Slovakia as a whole (tab. 3).

Tab 3. Recent changes in age structure of population of East Slovak small towns.

\begin{tabular}{|c|c|c|c|c|c|c|c|c|c|c|c|c|}
\hline & \multicolumn{3}{|c|}{$0-14$} & \multicolumn{3}{|c|}{$65+$} & \multicolumn{3}{|c|}{ average age } & \multicolumn{3}{|c|}{ total dependency ratio } \\
\hline & 2001 & 2014 & change & 2001 & 2014 & change & 2001 & 2014 & change & 2001 & 2014 & change \\
\hline Čierna nad Tisou & 22.0 & 15.0 & -7.0 & 4.5 & 9.4 & 4.9 & 30.7 & 38.3 & 7.6 & 36.1 & 32.2 & -3.9 \\
\hline Dobšiná & 25.4 & 25.3 & -0.1 & 14.8 & 9.5 & -5.3 & 32.5 & 33.7 & 1.2 & 67.1 & 53.3 & -13.8 \\
\hline Giraltovce & 24.7 & 17.1 & -7.6 & 7.4 & 9.9 & 2.6 & 31.0 & 36.2 & 5.2 & 47.2 & 37.1 & -10.1 \\
\hline $\begin{array}{l}\text { Hanušovce nad } \\
\text { Topl'ou }\end{array}$ & 27.1 & 19.5 & -7.6 & 7.9 & 9.0 & 1.1 & 30.3 & 34.8 & 4.5 & 54.0 & 39.9 & -14.1 \\
\hline Medzev & 24.6 & 23.6 & -0.9 & 9.2 & 9.8 & 0.6 & 32.6 & 34.1 & 1.5 & 51.0 & 50.3 & -0.6 \\
\hline Podolínec & 24.7 & 18.1 & -6.6 & 7.7 & 9.7 & 1.9 & 31.1 & 35.7 & 4.6 & 48.0 & 38.4 & -9.5 \\
\hline Spišská Stará Ves & 22.5 & 15.2 & -7.3 & 8.3 & 10.2 & 2.0 & 32.4 & 37.3 & 4.9 & 44.4 & 34.1 & -10.3 \\
\hline Spišské Podhradie & 22.9 & 17.0 & -5.9 & 10.7 & 12.2 & 1.5 & 33.7 & 37.6 & 3.9 & 50.7 & 41.3 & -9.3 \\
\hline Spišské Vlachy & 21.2 & 16.5 & -4.7 & 11.3 & 13.8 & 2.5 & 34.8 & 38.2 & 3.5 & 48.1 & 43.3 & -4.8 \\
\hline Strážske & 20.3 & 14.7 & -5.6 & 10.6 & 14.2 & 3.6 & 34.7 & 38.9 & 4.2 & 44.7 & 40.6 & -4.1 \\
\hline Vel'ký Šariš & 20.6 & 20.9 & 0.3 & 20.7 & 12.8 & -7.9 & 36.2 & 37.0 & 0.8 & 69.5 & 50.8 & -18.7 \\
\hline Vysoké Tatry & 15.4 & 10.2 & -5.2 & 13.4 & 19.5 & 6.2 & 38.5 & 44.4 & 5.9 & 40.5 & 42.4 & 1.9 \\
\hline Slovakia & 18.7 & 15.3 & -3.4 & 11.4 & 14.0 & 2.6 & 36.2 & 39.9 & 3.7 & 60.8 & 91.2 & 30.4 \\
\hline
\end{tabular}

Based on data from Annual registration of population by sex and age (SOSR 2001 - 2014a) 
With the exception of Vysoké Tatry, population of which is clearly the oldest among the analysed towns and even older than the average of Slovakia, the values of total dependency ratio in all small towns decreased, while considerably increased in Slovakia as a whole. This seems to be only temporal trend caused by shift of relatively big age cohorts from 0 - 14 to 15 - 64 age categories. On the other hand, shift of cohorts to 65+ age category was smaller and the age category 15 - 64 strengthened temporarily. Nevertheless, decrease in proportion of $0-14$ and increase of $65+$ age groups indicate the values of total dependency ratio will start to grow with some time lag, as it has been recently in Slovakia as a whole.

Considering development trends in individual small towns, changes in age structure of population indicate certain differences in demographic transformation. To assess them properly, natural reproduction and migration need to be examined. Annual average rates over the periods of 2001 - 2007 and 2008 - 2014 indicate general overview of natural reproduction, migration, and subsequently total population growth development. The values are provided for all analysed towns, as well as the average for rural and urban municipalities of Slovakia, and Slovakia as a whole, to enable comparisons (fig. 2).

Natural reproduction of population became stabilized nearing the equilibrium in Slovakia in 2000s (Mládek 2008). Nevertheless, urban municipalities in average recorded natural increase in Slovakia, while rural municipalities recorded natural decrease over the period $2001-2007$. With the exception of Strážske and Vysoké Tatry, all small towns recorded natural increase, what indicates development similar to average for all urban municipalities in East Slovakia. However, there is more or less significant proportion of Roma people in all small towns in Slovakia except for Vysoké Tatry. Specific reproductive behaviours of Roma population typical of high natality contribute to natural increase in analysed towns. In the towns reaching the largest natural increase in both periods (2001 - 2007 and 2008 - 2014) the Roma population constitutes the highest proportion (Medzev, Giraltovce, Hanušovce nad Topl'ou, Podolínec, and Dobšiná). At the same time, these towns reached the highest proportion of population with German or Hungarian ethnicity at the beginning of the $20^{\text {th }}$ century (tab. 2). This relation is the most notable in pre-industrial mining towns of Medzev and Dobšiná.

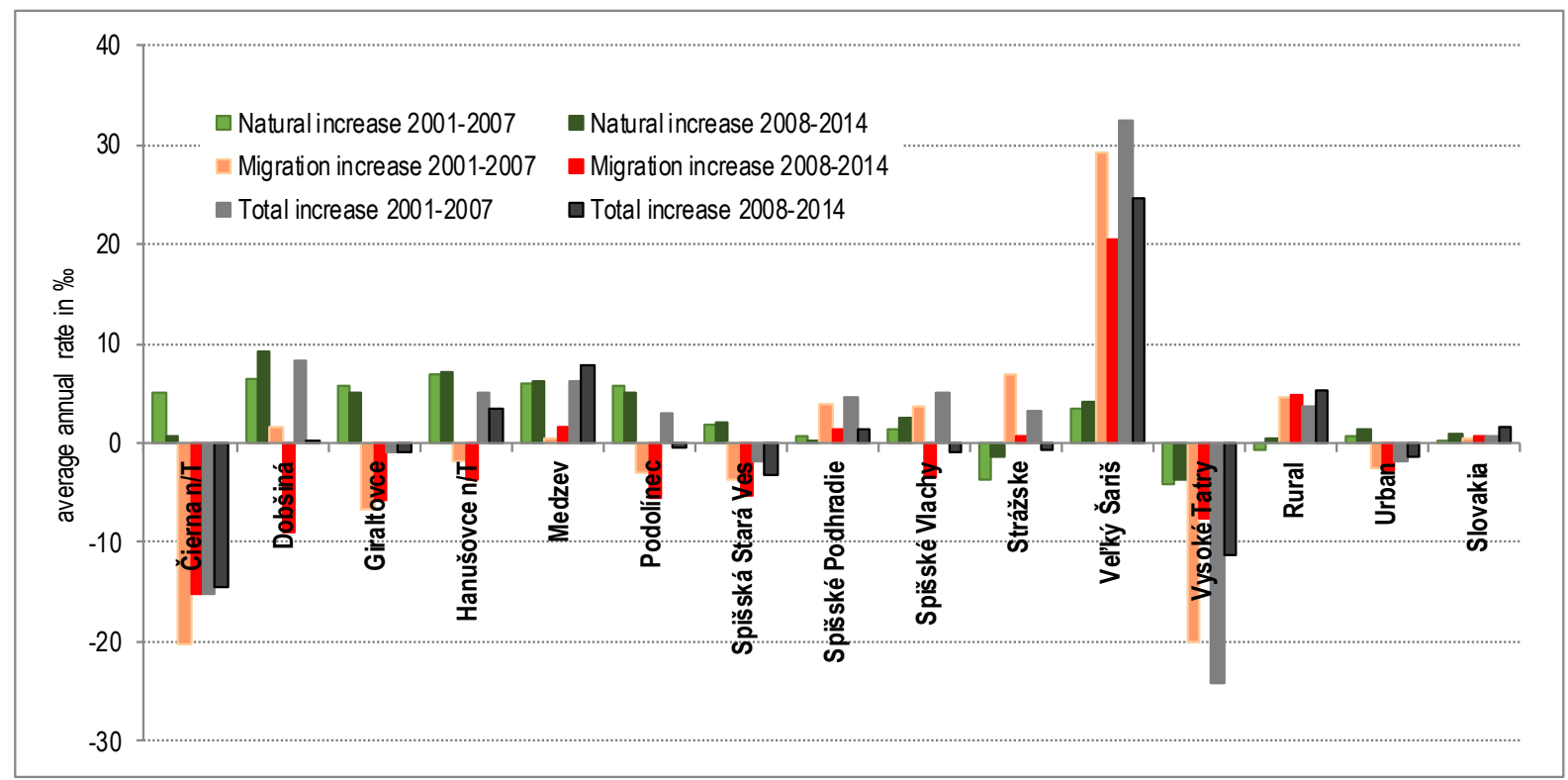

Fig 2. Total population growth and its components in small towns of East Slovakia, rural and urban communities of Slovakia, and Slovakia as whole over the 2001 - 2007 and 2008 - 2014 periods. Data source: Annual Registration of Population (SOSR 2001 - 2014b, 2003b)

Migration balance was positive in six and negative also in six towns over $2001-2007$ period. During the latter period the values of average net migration rate decreased in majority of towns and only four towns maintained migration gains. This indicates, similarly to development of natural increase that despite smaller populations, demographic trends in small towns of East Slovakia converge rather with average for urban than rural municipalities in Slovakia. Among all 
analysed small towns, the towns of Vysoké Tatry, Čierna nad Tisou and Vel'ký Šariš reached extreme values of average annual net migration rate in both observed periods. Vysoké Tatry and Čierna nad Tisou, established in the $20^{\text {th }}$ century, recorded considerable loss of population by migration. The numbers of immigrants to both of these towns were similar with other towns, but they were highly exceeded by the numbers of emigrants from these towns. This might be caused by very narrowly specialized economies of both towns to a single industry (tourism in Vysoké Tatry and railway traffic in Čierna nad Tisou) together with rising living costs in Vysoké Tatry and the decline of core industry in Čierna nad Tisou.

Vel'ký Šariš is located only $6 \mathrm{~km}$ from the centre of Prešov, the third largest town $(90,000$ inhabitants) in Slovakia. Thanks to suburbanization, the decentralization of population became the dominant process of spatial redistribution of population in the urban regions of all cities and larger towns in Slovakia (cf. Novotný 2011). Extreme population growth of Vel'ký Šariš by migration (ca. $2.5 \%$ annually) is likely to be a clear consequence of this process enhanced by favourable location in the proximity of Prešov, building stock with rather rural character, good accessibility to Prešov by public transportation and even attractive environment and landscape below the castle hill with the ruins of the medieval Šarišský hrad castle.

Generally given, (1) larger pre-industrial small-towns including the mining ones (Medzev, Dobšiná, Spišské Podhradie, Spišské Vlachy, Vel'ký Šariš) seem to keep their population size stabilized without extreme changes over the observed period since 1869 despite expulsion of Germans and subsequent re-settlement. These towns, especially Medzev and Dobšiná, were losing population until the Second World War and afterwards only insignificant population growth was recorded. Population growth of these towns in each time section over the period 1869 - 1991 was negative or positive but smaller than the growth of Slovakia as a whole. This indicates that development peak of these towns was recorded before 1869.

(2) Smaller pre-industrial towns and villages (Podolínec, Spišská Stará Ves, Giraltovce, Hanušovce nad Topl'ou, Strážske) recorded significant growth mainly after the Second World War, so by the end of socialist era (1989) they reached comparable size with the previous group.

(3) On one hand, newly established towns of Vysoké Tatry and Čierna nad Tisou recorded rapid growth during socialist period but started to decline considerably in the 2000s. On the other hand, Vel'ký Šariš located in close hinterland of Prešov seems to become part of the Prešov's suburban zone with rapid growth by migration in the 2000s.

(4) Almost all towns recorded positive balance of natural reproduction of population, what is related to significant proportion of Roma population settled especially in those towns, where population declaring German or Hungarian ethnicity constituted significant proportion by the end of the $19^{\text {th }}$ century. This enabled some pre-industrial towns (Dobšiná, Spišské Podhradie) to reach new peaks of population size by the end of period of observation.

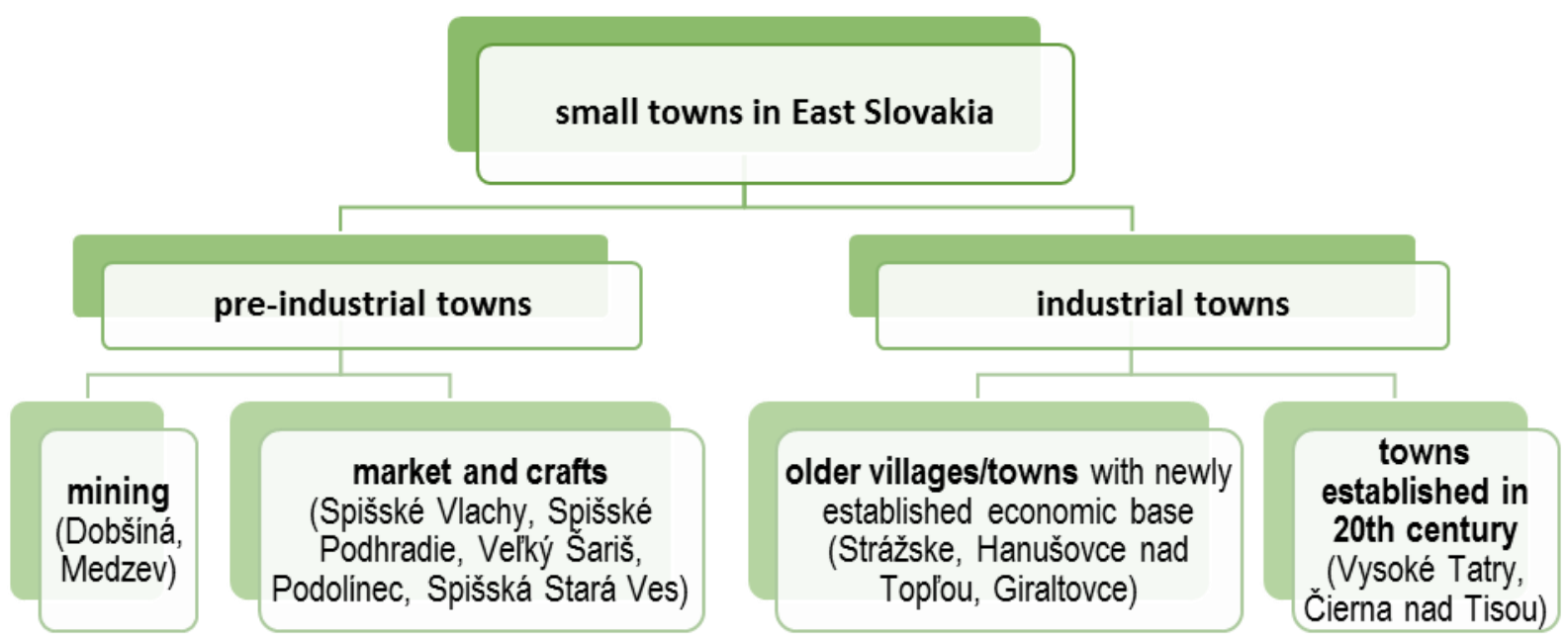

Fig 3. Categories of small towns in East Slovakia. 


\section{Economic transformation of small towns}

Demographic development went hand in hand with the economic performance. Each small town is different in its role in regional labour market and regional economy. The following section concerns the economic development to point at similarities and categorization of their development patterns.

Some of the analysed towns played an important economic role already in the Middle Ages (fig. 3) as they were centres of mining and processing of ores and metals (Dobšiná and Medzev), and centres of market and crafts (Spišské Vlachy, Spišské Podhradie, Vel'ký Šariš, Podolínec, and Spišská Stará Ves). Since their economic peak, these towns economically stagnated or even declined. Other towns (Strážske, Hanušovce nad Topl'ou, Giraltovce) did not have the economic base established until the $20^{\text {th }}$ century and their economic development is closely associated to socialist industrialization in the second half of the $20^{\text {th }}$ century. Similar pattern can be observed in the towns of Vysoké Tatry and Čierna nad Tisou, established just after the Second World War.

To assess the situation at the end of socialist industrialization (the 1991 data) and after the main phase of post-socialist transformation (the 2011 data) the data from the population censuses 1991 and 2011 are used.

By the end of the socialist period, the highest numbers of jobs for local people were provided in newly established towns of Vysoké Tatry and Čierna nad Tisou, followed by other industrial towns (Strážske, Giraltovce) and pre-industrial mining towns (Dobšiná, Medzev). Also the highest local demand satisfaction rate values in 1991 were recorded in industrial towns. On the other hand, the lowest numbers of jobs for local people and lowest local demand satisfaction rate values were reached by pre-industrial market and craft towns (Spišské Vlachy, Vel'ký Šariš, Spišské Podhradie, Spišská Stará Ves and Podolínec). Among these towns, specific situation was recorded in Spišská Stará Ves, where the number of jobs was relatively small but the local demand satisfaction rate reached almost $80 \%$ (tab. 4). This could be thanks to specific geographical location as the town is a centre of small, remote, and mountainous region. Due to these reasons, Spišská Stará Ves is also the smallest town in Slovakia that creates its own functional urban region delimited by Bezák $(2000,2014)$. This confirms that considering daily commuting, Spišská Stará Ves region is relatively enclosed. At the same time, Spišské Vlachy and Vel'ký Šariš are the only small towns where less than $50 \%$ of local economically active people were employed in 1991. This is the most likely consequence of their location in the proximity of important regional economic centres of Prešov, Spišská Nová Ves and Krompachy (not a large town by population but a centre of metallurgical and mechanical engineering industry with thousands of jobs provided by the end of socialist era) (Székely 1995, Spišiak and Kulla 2009).

On the other hand, Spišské Vlachy and Vel'ký Šariš are the towns with the lowest decrease of analysed indicator (12.2 and 12.1 percentage points respectively), even despite increase in number of economically active inhabitants. In 2011, no town reached 1000 jobs for locals. The largest decreases in jobs number and local demand satisfaction rate were recorded in Čierna nad Tisou, Vysoké Tatry and Strážske. The decrease of local demand satisfaction rate was observed alongside simultaneous decrease in number of economically active local people there. Surprisingly, significant decrease of both indicators was observed also in more historical Spišská Stará Ves, where number of economically active people increased over the period 1991 - 2011. 
Tab 4. Number of jobs provided by small towns for own inhabitants and satisfaction rate of local demand for jobs in 1991 and 2011.

\begin{tabular}{|c|c|c|c|c|c|c|c|c|c|}
\hline & \multicolumn{3}{|c|}{ number of jobs for locals } & \multicolumn{3}{|c|}{ economically active people } & \multicolumn{3}{|c|}{ local demand satisfaction rate } \\
\hline & 1991 & 2011 & $\begin{array}{r}\text { growth } \\
\text { index number }\end{array}$ & 1991 & 2011 & $\begin{array}{r}\text { growth } \\
\text { index } \\
\text { number }\end{array}$ & 1991 & 2011 & $\begin{array}{r}\text { difference } \\
\text { (in pp) }\end{array}$ \\
\hline Čierna nad Tisou & 1994 & 825 & $41.4 \%$ & 2312 & 2065 & $89.3 \%$ & $86.2 \%$ & $40.0 \%$ & -46.3 \\
\hline Dobšiná & 1496 & 858 & $57.4 \%$ & 2057 & 1610 & $78.3 \%$ & $72.7 \%$ & $53.3 \%$ & -19.4 \\
\hline Giraltovce & 1172 & 467 & $39.8 \%$ & 1890 & 1773 & $93.8 \%$ & $62.0 \%$ & $26.3 \%$ & -35.7 \\
\hline $\begin{array}{l}\text { Hanušovce nad } \\
\text { Topl'ou }\end{array}$ & 822 & 528 & $64.2 \%$ & 1493 & 1806 & $121.0 \%$ & $55.1 \%$ & $29.2 \%$ & -25.8 \\
\hline Medzev & 1217 & 495 & $40.7 \%$ & 1855 & 1782 & $96.1 \%$ & $65.6 \%$ & $27.8 \%$ & -37.8 \\
\hline Podolínec & 852 & 401 & $47.1 \%$ & 1352 & 1595 & $118.0 \%$ & $63.0 \%$ & $25.1 \%$ & -37.9 \\
\hline Spišská Stará Ves & 836 & 288 & $34.4 \%$ & 1051 & 1130 & $107.5 \%$ & $79.5 \%$ & $25.5 \%$ & -54.1 \\
\hline Spišské Podhradie & 847 & 498 & $58.8 \%$ & 1562 & 1780 & $114.0 \%$ & $54.2 \%$ & $28.0 \%$ & -26.2 \\
\hline Spišské Vlachy & 636 & 449 & $70.6 \%$ & 1619 & 1656 & $102.3 \%$ & $39.3 \%$ & $27.1 \%$ & -12.2 \\
\hline Strážske & 1771 & 496 & $28.0 \%$ & 2171 & 2028 & $93.4 \%$ & $81.6 \%$ & $24.5 \%$ & -57.1 \\
\hline Vel'ký Šariš & 749 & 590 & $78.8 \%$ & 2019 & 2357 & $116.7 \%$ & $37.1 \%$ & $25.0 \%$ & -12.1 \\
\hline Vysoké Tatry & 2599 & 276 & $10.6 \%$ & 3124 & 2058 & $65.9 \%$ & $83.2 \%$ & $13.4 \%$ & -69.8 \\
\hline Slovakia & $\mathbf{x}$ & $\mathbf{x}$ & $\mathrm{x}$ & $\begin{array}{r}2 \\
617935\end{array}$ & $\begin{array}{r}2630 \\
052 \\
\end{array}$ & $100.5 \%$ & $\mathbf{x}$ & $\mathbf{x}$ & $\mathrm{x}$ \\
\hline
\end{tabular}

Based on data from the 1991 and 2011 census (SOSR 1991, 1994b, 2011a)

To understand development trends better, situations in 1991 and 2011 are analysed by the total number of jobs (tab. 5) showing that beside considerable decrease in number of jobs for local people, Spišská Stará Ves recorded the most significant decrease in number of commuters. This indicates that during the post-socialist transformation period, the town's economy was strongly affected by unfavourable location and other determinants of development.

Tab 5. Number of commuters and total number of jobs in small towns in 1991 and 2011.

\begin{tabular}{|c|c|c|c|c|c|c|}
\hline & \multicolumn{3}{|c|}{ number of commuters to town } & \multicolumn{3}{|c|}{ total number of jobs in town } \\
\hline & 1991 & 2011 & growth index number & 1991 & 2011 & growth index number \\
\hline Čierna nad Tisou & 3927 & 2134 & $54.3 \%$ & 5921 & 2959 & $50.0 \%$ \\
\hline Dobšiná & 567 & 278 & $49.0 \%$ & 2063 & 1136 & $55.1 \%$ \\
\hline Giraltovce & 1276 & 512 & $40.1 \%$ & 2448 & 979 & $40.0 \%$ \\
\hline $\begin{array}{l}\text { Hanušovce nad } \\
\text { Topl'ou }\end{array}$ & 888 & 316 & $35.6 \%$ & 1710 & 844 & $49.4 \%$ \\
\hline Medzev & 338 & 174 & $51.5 \%$ & 1555 & 669 & $43.0 \%$ \\
\hline Podolínec & 478 & 253 & $52.9 \%$ & 1330 & 654 & $49.2 \%$ \\
\hline Spišská Stará Ves & 791 & 229 & $29.0 \%$ & 1627 & 517 & $31.8 \%$ \\
\hline Spišské Podhradie & 705 & 384 & $54.5 \%$ & 1552 & 882 & $56.8 \%$ \\
\hline Spišské Vlachy & 441 & 300 & $68.0 \%$ & 1077 & 749 & $69.5 \%$ \\
\hline Strážske & 4248 & 1471 & $34.6 \%$ & 6019 & 1967 & $32.7 \%$ \\
\hline Vel'ký Šariš & 1956 & 789 & $40.3 \%$ & 2705 & 1379 & $51.0 \%$ \\
\hline Vysoké Tatry & 4998 & 2047 & $41.0 \%$ & 7597 & 2323 & $30.6 \%$ \\
\hline Slovakia & $x$ & $x$ & $\mathbf{x}$ & $\mathbf{x}$ & $\mathbf{x}$ & $\mathbf{x}$ \\
\hline
\end{tabular}

Based on the 1991 and 2011 census data (SOSR 1991, 1994a, 2011a)

Spišská Stará Ves is the only pre-industrial town that recorded such a sharp economic decline. Despite population growth recorded by 2011 (tab. 1), increasing migration losses after 2000 (fig. 3) indicate the economic decline would be followed by population decline. This might be connected with the geopolitical vulnerability of the region. The town used to be market town and natural centre of the Zamagurie region (subregion of northern Spiš) and became the seat of Magura district in the end of the $18^{\text {th }}$ century. However, after the First World War significant part of the district became a part of Poland and the district was entirely abolished in 1960. Other small towns in Spiš region (Spišské Vlachy, Spišské Podhradie, Podolínec) also lost their 
administrative functions after the First World War, but only Spišská Stará Ves lost considerable part of its natural hinterland.

The number of jobs and number of commuters in all analysed towns recorded decreases. This is a general attribute of post-socialist transformation but East Slovakia was affected especially strongly by new phenomena of unemployment. Regarding data from population censuses (SOSR 1991, 2001, 2011a), the rate of unemployment grew extremely from less than $5 \%$ in 1991 to over $25 \%$ in 2001 and in 2011 was still only slightly below $25 \%$. In this light the decline in the number of jobs in small towns is not that fundamental. Nevertheless, it is clear that decreases in pre-industrial towns (with exception of Spišská Stará Ves) were lower than those in industrial towns. The exception (opposite to Spišská Stará Ves) is Čierna nad Tisou. Number of commuters decrease was relatively low. Considering significant decrease in number of economically active inhabitants (tab. 4) as well as total population size (tab. 1) driven mainly by strong migration out-flow (fig. 3), it is assumed that many inhabitants decided to move to adjacent rural municipalities with more attractive environment but remained tied with the town by commuting flows. On the other hand, Spišské Vlachy had the lowest number of jobs for own inhabitants (tab. 4) and the lowest total number of jobs (tab. 5) in 1991, but recorded the least significant decline in total number of commuters and total number of jobs (tab. 5), and reports one of the smallest declines in number of jobs for own inhabitants and the local demand satisfaction rate (tab. 4) respectively.

With the exception of Spišská Stará Ves and Čierna nad Tisou, recent economic development indicates two basic trends. (1) Pre-industrial towns seem to have built specific position in regional economies, which became more or less stabilized over the centuries, despite considerable temporal fluctuations. Those towns recorded demographic and economic turbulences (e.g., expulsion of population, settling of new population, decline of traditional industries) but seem to keep stabilized population size, although various trajectories of population growth have been recorded over the past two decades. On the other hand (2) industrial towns recorded substantial economic and demographic growth during socialist industrialization, but they are coping much worse with the post-socialist transformation.

The reason might origin in nature of socialist industrialization. Economies of newly industrialized towns were often based on the operation of a single big factory (often localized by political order regardless town's geographic preconditions) employing hundreds or even thousands of workers, while the economies of pre-industrial towns were based on smaller factories or enterprises. Socialist industrialization was not that rapid in majority of these towns (Spišská Stará Ves and Velký Šariš are the exceptions). This helped them to deal with changing conditions under post-socialist transformation better. To assess the relevance of these assumptions, the following section analyses the changes in structure of economies in small towns by the economic sectors.

We brought five economic sectors to assess the character of economy and its change between 1991 and 2011 in each town. As indicated in fig. 4, after socialist decades, industry and construction was a dominant category in a structure of jobs in majority of small towns in 1991. Economic activities in newly established towns were dominated by the sectors development of which led to the establishment of these towns (transport in Čierna nad Tisou, health care, tourism and associated services in Vysoké Tatry). Employment structure of pre-industrial mining towns was similar to these industrial. On the other hand, in Podolínec and Spišské Vlachy, the employment in agriculture was higher than in industry. Difference between number of jobs in agriculture and industry was relatively small also in Spišské Podhradie. Despite specific features of development in each town, some regularity is possible to be identified. To sum it up:

(1) After 1991, the employment in agriculture decreased considerably in a whole country. The number of jobs dropped to one third by 2011. Nevertheless, decrease in East Slovak small towns was fundamental. In eight out of twelve towns the number of jobs in agriculture and forestry fell by four fifths during two decades. Decrease was more moderate only in preindustrial mining and newly established towns, where this sector had never played a key role in local economy (excluding forestry in Vysoké Tatry). 
(2) Spišské Vlachy, the least industrialized small town by 1991, is the only town where the number of jobs in industry and construction increased by 2011. All other towns recorded decreases (more intensive than Slovakia as a whole). It is possible to conclude in general that the numbers of jobs decreased most significantly in the sectors leading prior to 1991.

(3) Despite decreases also in numbers of jobs in trade and other services in some towns, this economic sector became the most important employer in five towns. In six towns, industry and construction remained the most important employer but the differences between numbers of jobs in industry and construction, and trade and services diminished.

(4) Specific economic features of newly established towns remained distinct even by 2011. Number of jobs in transport and communication fell almost by two thirds in Čierna nad Tisou, however, due to decrease in total number of jobs by $50 \%$ (tab. 5) it constituted more than half of all jobs in the town in 2011. In Vysoké Tatry, total number of jobs in 2011 was only about $30 \%$ of 1991. Vysoké Tatry was established as climatic spa and touristic resort. Despite considerable reduction in number of jobs in market and services and especially in health care, these sectors still constituted almost four fifths of all jobs in town in the 2011.

(5) Significant decreases in formerly key economic sectors and generally more intensive declines than in Slovakia as a whole in all sectors, together with weakened ability to satisfy demand of local people for jobs indicate that position of small towns in regional economies diminished. Small towns seem to be losing in competition with bigger towns or rural areas. However, relative decline of significance in regional economies is much smaller since decline in number of jobs has affected East Slovakia as a whole what results in unemployment rate exceeding $20 \%$. Moreover, rapid declines in numbers of jobs in agriculture and forestry might be also seen as development from rural to urban character. Also increases in number of jobs in market and services in majority of analysed towns indicate they keep or even strengthen their position of sub-regional centres of retail and services. Nonetheless, lowering values of local demand satisfaction rate (tab. 4) might signify deepening integration of regional labour market associated with improvement of labour mobility. To obtain more detailed insight into the position of small towns in regional labour markets, changes in spatial extent of commuting areas of given small towns are examined in the following section.

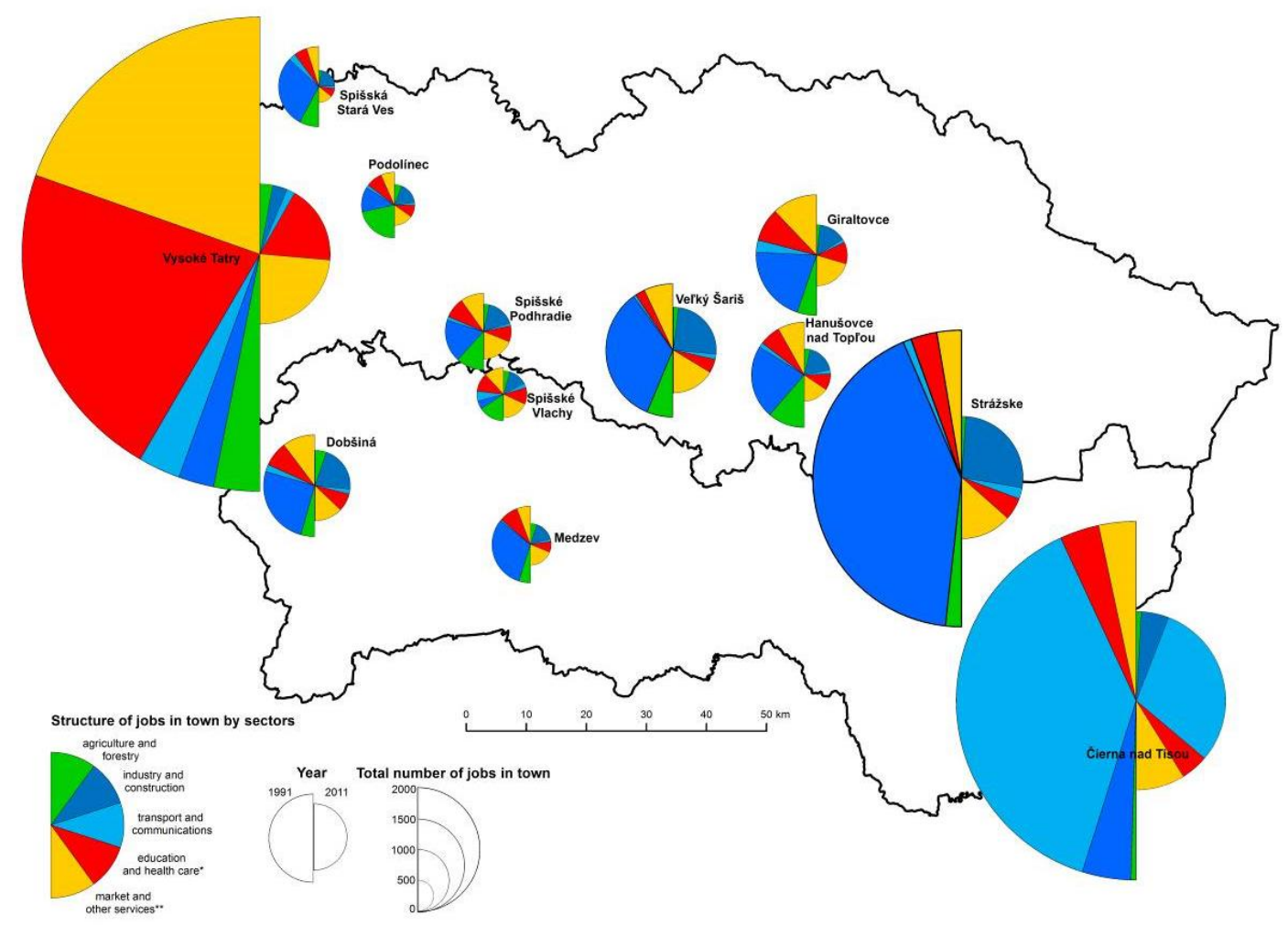

Fig 4. Number of jobs and their structure in 1991 and 2011; based on data by SOSR (1991, 1994a, 2011a); * including culture in 1991, and public administration in 2011; ** including unidentified economic sector in 2011. Own calculation based on the 1991 and 2011 census data (SOSR 1991, 1994a, 2011a) 


\section{Commuting zones of small towns}

Decrease in total number of jobs (tab. 6) goes hand in hand with decrease in number of commuters to towns. As indicated by fig. 5, the highest absolute decreases were recorded in the towns, which were the largest centres of employment in 1991. It particularly applies to Čierna nad Tisou, Vysoké Tatry and Strážske, followed by Vel'ký Šariš and Giraltovce with more than 1000 commuters each in 1991. Despite declines, Čierna nad Tisou, Vysoké Tatry and Strážske were commuting destinations for over 1000 workers even in 2001 and 2011.

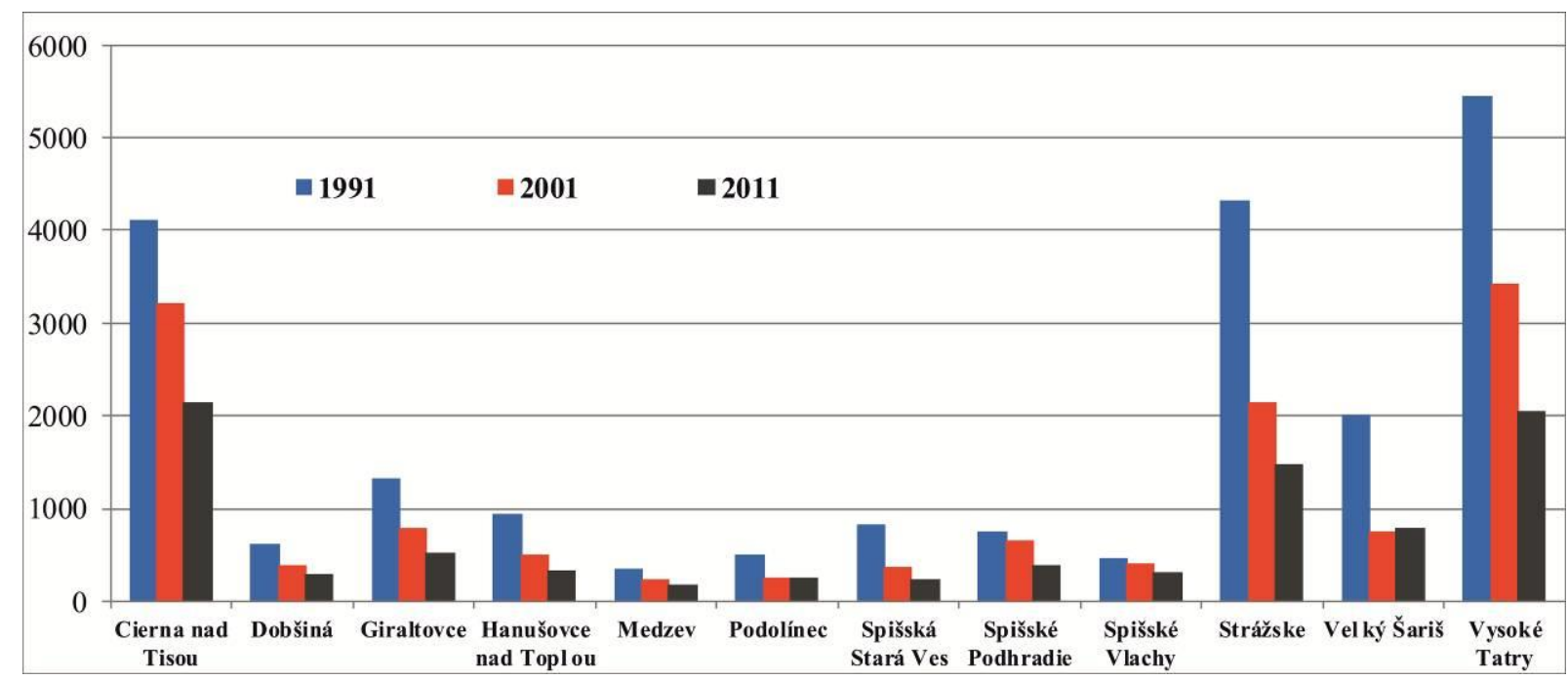

Fig 5. Numbers of commuters to small towns in 1991, 2001 and 2011. Based on data from population censuses (SOSR 1994, 2001, 2011a)

All towns, despite various patterns, recorded continuous decreases in the number of commuters. The number of commuters fell by more than $50 \%$ between 1991 and 2001 in Strážske, Spišská Stará Ves and almost by two thirds in Vel'ký Šariš. In the latter period, declines were much more moderate, indicating post-transformation stabilization of local economies. Vel'ký Šariš is the only town that recorded even slight increase in the number of commuters between 2001 and 2011. This seems to be a result of two factors. Brewery of Pivovar Šariš that used to be the largest employer after the socialist industrialization experienced a remarkable revival after its acquisition by SAB Miller global group which acquired several breweries in Slovakia, closed majority of them and concentrated production to Vel'ký Šariš after 2001. Moreover, local company GOHR invested a lot to modernize the production by 2011 and has almost 300 employees in Vel'ký Šariš. The company works on a basis of SAP information system (GOHR 2015), where need for highly educated and skilled employees might be stimulus for commuting.

Considering relative values, similar development was observed in Podolínec, where after sharp decrease during the period 1991 - 2001, the number of commuters remained almost the same during the period $2001-2011$.

The smallest relative decreases during the 1991 - 2001 period, by less than one fifth, were recorded in Spišské Vlachy and Spišské Podhradie, followed by Čierna nad Tisou. Despite significant fell of absolute number of commuters as well as decrease in the number of jobs in Čierna nad Tisou, the relative decline in number of commuters was moderate in the both intercensal periods. As already mentioned before (tab. 5), the smallest decreases in number of commuters over the whole 1991 - 2011 period were recorded in the pre-industrial towns with no large investments during socialist industrialization. Numbers of commuters to other towns decreased more significantly and with the exceptions of Vysoké Tatry, Čierna nad Tisou and Strážske, they rather converged with the numbers to less industrialized pre-industrial towns.

However, aforementioned patterns only partially correspond with the changes in spatial extent of commuting hinterlands (fig. 6). Development of commuting to each town is unique. On the whole, following three patterns can be recognised. 


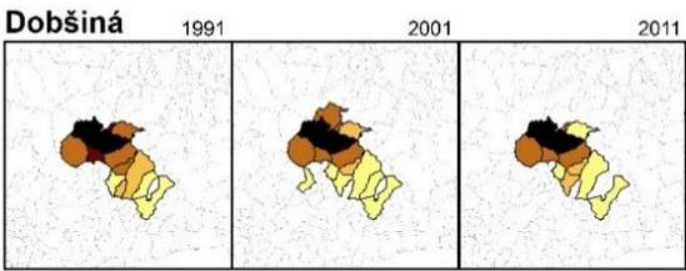

Hanušovce nad Toplou

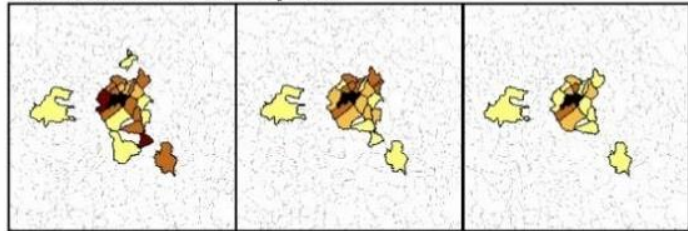

Podolínec

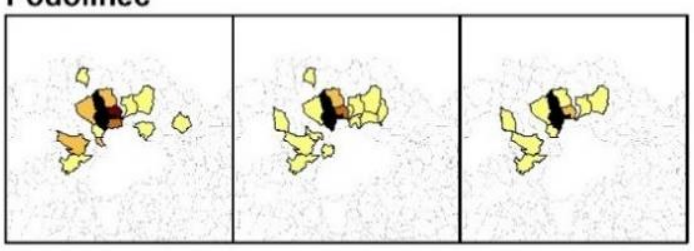

Spišské Podhradie

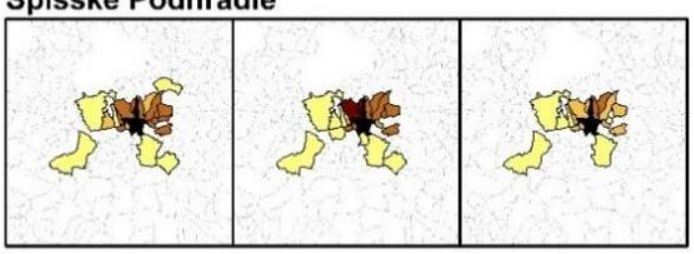

Strážske

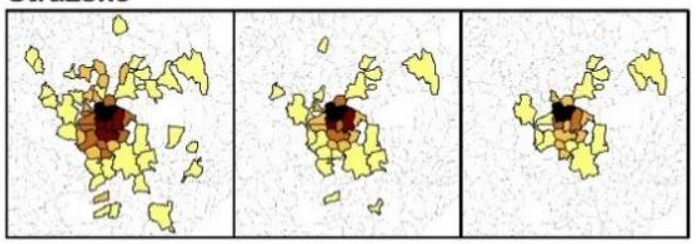

Čierna nad Tisou

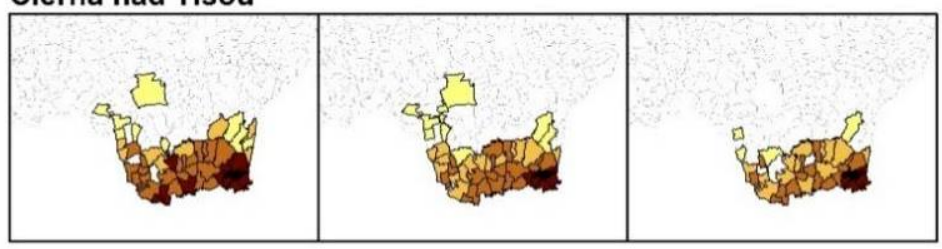

Vysoké Tatry

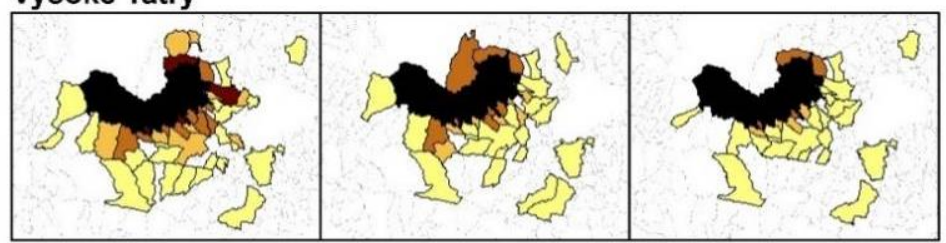

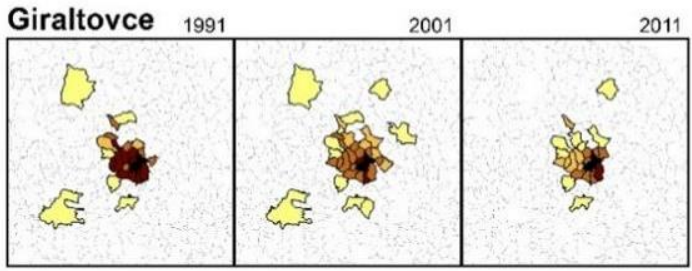

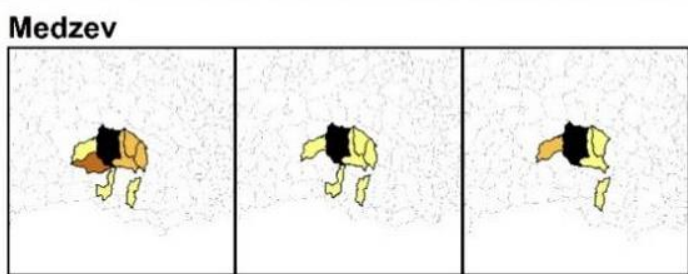

Spišská Stará Ves
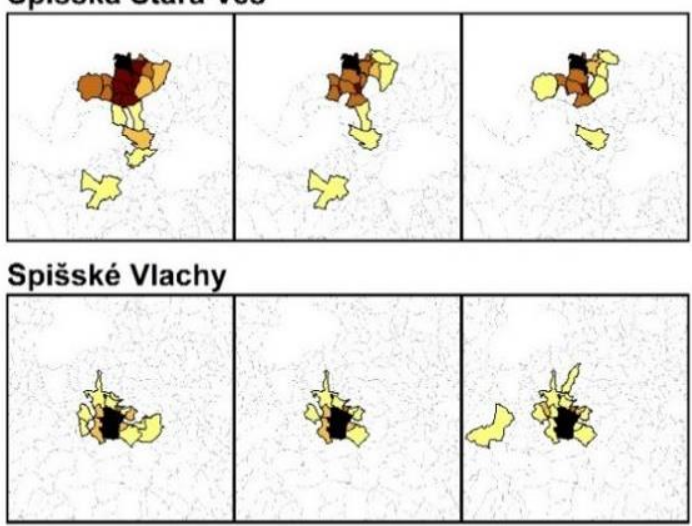

Vel'ký Sariš
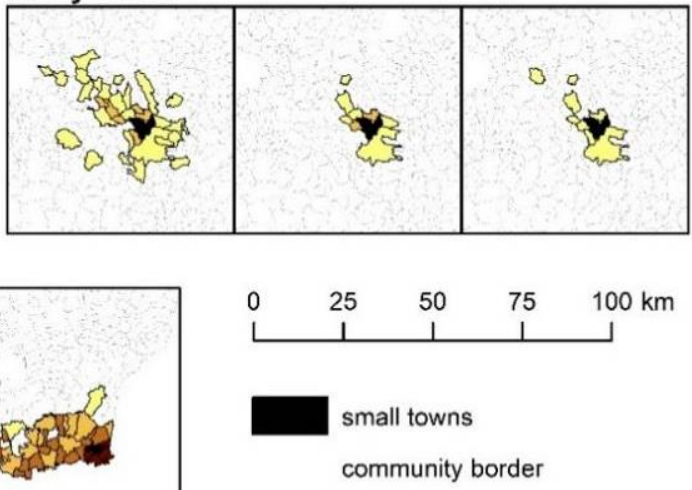

proportion in \%

0,01- 5,00

$\square, 01-10,00$

$\square 10,01-25,00$

25,01 and more

Fig 6. Commuting zones of small towns in 1991, 2001 and 2011; *proportion of persons commuting to each small town on total number of economically active persons in community. Based on population censuses data (SOSR 1991, 2001, 2011a)

(1) Newly established towns of Vysoké Tatry and Čierna nad Tisou lost more or less $50 \%$ of commuters during the 1991 - 2011 period. However, the spatial extent of their commuting zones shrank only slightly and remained the largest among all studied towns. This may be explained by two major reasons. Firstly, economic base of each of these towns is dominated by specific sector, which requires employees with specific skills, knowledge and practice and it is difficult to find quality labour force in a town itself or in its proximity. The latter possible reason is the rapid population loss by migration. Migrants could have moved from these towns to other towns or 
neighbouring municipalities, seeking better environmental or economic reasons, but remained tied with Čierna nad Tisou and Vysoké Tatry by commuting.

(2) Newly industrialized towns as well as some pre-industrial towns, the economy of which boomed thanks to socialist industrialization, seem to have recorded significant decline in number of commuters as well as considerable shrinkage of their commuting zones. This goes in line with observed decline of key sectors followed by decrease of importance of these towns as regional centres of employment. This is most significant in Strážske, followed by Vel'ký Šariš, Giraltovce, Hanušovce nad Topl'ou and Spišská Stará Ves. Surprising is the development in Vel'ký Šariš, where the increase in number of commuters was recorded between 2001 and 2011 but the spatial extent of commuting zone kept on shrinking. This is because of the decisive role of commuting flow from neighbouring city of Prešov, which represents approximately one third one half of all commuters to Vel'ký Šariš. This is accompanied by growing flow from nearby town of Sabinov. At the same time, statistics show increase in number of commuters within the district with so few commuters that they were not reported for particular municipalities.

(3) Pre-industrial mining towns of Dobšiná and Medzev had relatively small commuting zones in 1991. This might be caused by mountainous areas with worse transport accessibility from nearby municipalities. The commuting zones of these towns even shrank a little by 2011 , but it was not as significant as in case of previous group of towns. Medzev became the town with the smallest commuting zone by 2011. It can be assumed that the town became integral part of the Košice city hinterland (cf. Novotný 2014). Analogical development with mining towns is observable in pre-industrial market and craft towns not strongly industrialized during socialist industrialization (Spišské Podhradie, Spišské Vlachy, Podolínec). The commuting zones of these towns are slightly larger and did not record considerable spatial shrinkage, but the size of commuting flows weakened within the zones. Together with Dobšiná and Medzev, these were the towns with the lowest numbers of commuters in 1991 but their absolute numbers decreased the least by 2011 .

\section{Conclusions}

In the paper, we sought to analyse various aspects of the demographic and economic transformation of small towns in East Slovakia to understand their development trajectories, changing functions in settlement system and position in settlement hierarchy. In doing so, we have set a criterion of 2000 - 5000 inhabitants at least in one of the 1991, 2001 or 2011 censuses to get a group of twelve small towns. Having investigated their historical, demographic and economic similarities and differences we traced their development patterns and perspectives.

The historical context of town-forming process was provided in brevity. Pre-industrial towns in the territory of Slovakia started to be established in the period of early feudalism alongside the intensive development of medieval towns in Europe, mainly in the course of the $11^{\text {th }}-16^{\text {th }}$ centuries. An important moment was, when the King Bela IV invited Germans to come to settle the territory of today's Slovakia after the Mongolian invasion. During pre-industrial era, many market, craft and mining towns were granted privileges which supported their development. After the $16^{\text {th }}$ century, there were no significant impulses for establishment of new towns or rapid development of those already existing, until the $19^{\text {th }}$ century, when expansion of railway transportation induced considerable development of some towns. The $20^{\text {th }}$ century urban development was closely associated with the period of socialist industrialisation, and the 1990s onwards was a period of post-socialist transformation processes.

The studied towns are performing specific demographic and economic development, as evidenced in the main text of this paper. In consecutive years there were periods of their dynamic growth, altering the phases of their decline.

Overall stated, small towns in East Slovakia grapple with many socio-economic problems. Their location in East Slovakia as the least developed region within the country does not favour their performance either. The key periods of their recent development were linked to socialist industrialisation and post-socialist transformation. Most of small towns record population stagnation; some of them rise only thanks to Roma population or suburbanisation process. From 
the economical point of view, small towns decreased in their dominant industries, the aftermath of what is that some of them lost the regional functions and become significant only sub-regionally. Despite the unfavourable facts it can be concluded that small towns are still being the niches for their hinterlands.

It is possible to distinguish certain differences patterns of development between two main categories of small towns, the pre-industrial and industrial towns. Pre-industrial towns reached their development peak before modern population censuses were launched in the $19^{\text {th }}$ century. Although they were originally important regional or even national urban nodes, they missed latter development impulses or caught them only partially. So their importance in settlement hierarchy declined in favour of other towns, mainly since the expansion of railway traffic in the $19^{\text {th }}$ century and later during the socialist industrialization and urbanization. Nevertheless, over the centuries these towns have repeatedly undergone economic and demographic transformation which helped them to keep the traits of town, unlike many other pre-industrial towns that became rural in character or even disappeared. The fact these towns were not substantially transformed under socialist industrialization enabled them to preserve their historical character and relatively diversified local economies. These towns have seemingly coped relatively successfully with postsocialist transformation. Generally, despite certain short-term fluctuations, these towns are likely to be relatively stable in long-term perspective. Although they lost their historical positions of urban centres of regional or national importance, they have kept their position of sub-regional urban nodes.

Within group of pre-industrial towns, specific situation is observed in case of former mining towns. Since rapid decline of their key economic sector, they were not able to transform their economic basis, which may be attributed to geographic conditions providing only limited potential for development of other economic activities under market economy conditions. This leads to continuous decline in the settlement hierarchy and beside significant migration loss, growth of population is achieved mainly due to high natural increase of Roma population.

Some small towns had rather rural character prior the socialist industrialization era. By political decision, huge investments into industrial plants were directed to these municipalities, often regardless the real geographical potential of the locality. Economic base often comparable with much bigger towns was built quickly what was followed by growth of population. The position of these industrial towns in settlement hierarchy often outperformed position of pre-industrial towns. However, these towns have been coping much worse with post-socialist transformation. This is very similar with the towns established just in the $20^{\text {th }}$ century. More or less substantial transformation of economic basis is evidenced as new phenomenon in these towns. It is clear that industrial towns also play important role in settlement system as sub-regional nodes and provide services, retail and job opportunities for their hinterlands, but they lost much more than preindustrial towns in comparison with the socialist era.

\section{Acknowledgement}

This work was supported by grant VEGA 1/0473/14 and the Slovak Research and Development Agency under the contract No. APVV-15-0306.

References

[1] Bezák, A. (2000). Funkčné mestské regióny na Slovensku. Geographica Slovaca, 15, Bratislava: Geografický ústav SAV.

[2] Bezák, A. (2006). Vnútorné migrácie na Slovensku: súčasné trendy a priestorové vzorce. Geografický časopis, 58, 15-44.

[3] Bezák, A. (2014). Funkčné mestské regióny na Slovensku v roku 2001. In Lauko, V. et al., eds., Regionálne dimenzie Slovenska (169-198). Bratislava: Univerzita Komenského.

[4] Chemko (2015). The company. Available at: http://www.chemko.sk. 
[5] FSO (1984). Statistický lexikon ČSSR 1982 Díl 1, 2. Praha: Federal Statistical Office.

[6] Gabal, I. (1999). Etnické menšiny ve střední Evropě. Praha: G plus G.

[7] GOHR (2015). Company profile. Available at: http://www.gohr.sk/index.php?option=com_\%20content\&view=article\&id=29\&ltemid=51\&la $\mathrm{ng}=\mathrm{en}$.

[8] Kačerová, M. (2009). Populačné starnutie obyvatel'stva Slovenska. In Bleha, B., ed., Populačný vývoj Slovenska na prelome tisícročí - kontinuita či nova éra? (pp. 105-125). Bratislava: Geografika.

[9] Knox, P. \& Mayer, H. (2013). Small Town Sustainability - Economic, Social and Environmental Innovation. Basel: Birkhäuser.

[10] Kresl, K. P. \& letri, D. (2016). Small Cities in a World of Competitiveness. New York: Routledge.

[11] Kropilák, M., ed. (1978). Vlastivedný slovník obcí na Slovensku III. Bratislava: Veda.

[12] Kropilák, M., ed. (1977a). Vlastivedný slovník obcí na Slovensku II. Bratislava: Veda.

[13] Kropilák, M., ed. (1977b). Vlastivedný slovník obcí na Slovensku I. Bratislava: Veda.

[14] Majo, J. (2012). Historicko-demografický lexikon obcí Slovenska 1880 - 1910 (Štruktúra obyvatel'stva podl'a materinského jazyka a náboženskej príslušnosti). Bratislava: Štatistický úrad Slovenskej republiky.

[15] Marenčáková, J. (2006). Ethnic structure of population. In Mládek, J. et al., eds., Demogeographical analysis of Slovakia (pp. 101-107). Bratislava: Comenius University.

[16] Marsina, R. (1973). K vývoju miest na Slovensku do začiatku 15. storočia. Historický časopis, 21, 337-369.

[17] Mládek, J. (1990). Teritoriálne priemyselné útvary Slovenska. Bratislava: Univerzita Komenského.

[18] Mládek, J. (2008). Stabilizácia populačného vývoja Slovenska na úrovni stacionárnej populácie. Acta Geographica Universitatis Comenianae, 50(1), 63-78.

[19] Mládek, J. \& Kačerová, M. (2008). Analysis of Population Ageing in Slovakia: time and regional dimensions. Geografický časopis, 60(2), 179-197.

[20] Mušinka, A. et al. (2014). Atlas rómskych komunít na Slovensku 2013. Bratislava: UNDP Bratislava Regional Centre. Available at: http://www.minv.sk/?atlas_2013.

[21] Novotný, L. (2014). Procesy priestorovej redistribúcie obyvatel'stva a ich vplyv na zmeny štruktúry obyvatel'stva vo funkčnom mestskom regióne Košice. Košice: Univerzita Pavla Jozefa Šafárika.

[22] Ouředníček, M. (2003). Suburbanizace Prahy. Sociologický časopis, 39, 235-253.

[23] Pašiak, J. (1980). Človek a jeho sídla. Bratislava: Obzor.

[24] Podolák, P. (2000). Geografické a demografické charakteristiky rómskeho obyvatel'stva na Slovensku. Geografický časopis, 52, 269 - 284.

[25] Pukačová, J. \& Mládek, J. (2014). Špecifické črty reprodukčného správania rómskeho obyvatel'stva na Slovensku. Geografický časopis, 66, 133-159.

[26] Schneidewind, P. et al., (2006). The Role of Small and Medium-Sized Towns (SMESTO), [Final Report]. Vienna: ESPON.

[27] Servillo, L. (2014). TOWNs in Europe. Available at: http://www.esponontheroad.eu/dane/web_articles_files/2082/servillo_town_in_europe.pdf

[28] Slavík, V. \& Grác, R. (2009). Proces urbanizácie a migrácia obyvatel'stva v kontexte vývoja sídelnej štruktúry Slovenskej republiky. In Bleha, B., ed., Populačný vývoj Slovenska na prelome tisícročí - kontinuita či nová éra? (pp. 236-256). Bratislava: Geo-grafika. 
[29] SOSR (1991). Results of the 1991 population and housing census. Bratislava: Statistic Office of Slovak Republic (SOSR). Available at: http://sodb.infostat.sk/sodb/eng/1991/format.htm.

[30] SOSR (1994a). Dochádzka do zamestnania, škôl a učenia (výsledky sčítania ludu, domov a bytov 1991). Bratislava: Statistic Office of Slovak Republic (SOSR).

[31] SOSR (1994b). Štatistický lexikón obcí Slovenskej republiky 1992. Bratislava: Statistic Office of Slovak Republic (SOSR), 280 p.

[32] SOSR (2001-2014a). Annual Registration of Population by Sex and Age. Bratislava: Statistic Office of Slovak Republic (SOSR).

[33] SOSR (2001-2014b). Annual Registration of Population. Bratislava: Statistic Office of Slovak Republic (SOSR).

[34] SOSR (2001). Results of the 2001 population and housing census. Bratislava: Statistic Office of Slovak Republic (SOSR). Available at: http://sodb.infostat.sk/sodb/eng/2001/format.htm.

[35] SOSR (2003a). Historický lexikón obcí SR 1970-2001. Bratislava: Statistic Office of Slovak Republic (SOSR), $508 \mathrm{p}$.

[36] SOSR (2003b). Štatistický lexikón obcí Slovenskej republiky 2002. Bratislava: Statistic Office of Slovak Republic (SOSR), 344 p.

[37] SOSR (2011a). Results of the 2011 population and housing census. Bratislava: Statistic Office of Slovak Republic (SOSR). Available at: http://census2011.statistics.sk/.

[38] SOSR (2011b). Štatistický lexikón obcí Slovenskej republiky 2011. Bratislava: Statistic Office of Slovak Republic (SOSR), $340 \mathrm{p}$.

[39] Spišiak, P. \& Kulla, M. (2009). Priemysel Dolného Spiša s dôrazom na podnik Embraco Slovakia Spišská Nová Ves. Geographia Moravica, 1, 71-83.

[40] Steinführer, A. \& Haase, A. (2007). Demographic Change as a Future Challenge for Cities in East Central Europe. Geografiska Annaler, 89B, 183-195.

[41] Sýkora, L. \& Mulíček, O. (2009). The micro-regional nature of functional urban areas (FUAs): lessons from the analysis of the Czech urban and regional system. Urban Research \& Practice, 3(2), 287-307. DOI: 10.1080/17535060903319228.

[42] Székely, V. (1995). Formovanie priemyselnej štruktúry Spiša v rokoch 1948 - 1985. In Spiš v kontinuite času: zborník z medzinárodnej vedeckej konferencie (pp. 329-339). Prešov: Universum.

[43] Šprocha, B. (2011). Vnútorná migrácia podla najvyššieho dosiahnutého vzdelania na Slovensku. Prognostické práce, 3, 213-246.

[44] Šprocha, B. (2014). Reprodukcia rómskeho obyvatel'stva na Slovensku a prognóza jeho populačného vývoja. Bratislava: INFOSTAT.

[45] ÚKLKas MV (1966). Statistický lexikon obcí ČSSR 1965. Praha: Ústřední komisie lidové kontroly a statistiky a ministerstvo vnítra (ÚKLKas).

[46] Uličný, F. (1992). Dejiny Giraltoviec. Košice: Východoslovenské vydavatel'stvo.

[47] Vaishar, A. et al. (2012). Malá města - motory rozvoje jihomoravského venkova. Brno: Mendelova univerzita v Brně.

[48] Verešík, J. (1974). Vidiecke sídla. In Lukniš, M., Princ, J. et al., eds., Slovensko - L'ud, $1^{\text {st }}$ part (pp. 463-522). Bratislava: Obzor. 